Article

\title{
What about Gender in Climate Change? Twelve Feminist Lessons from Development
}

\author{
Anne Jerneck
}

Lund University Centre for Sustainability Studies, LUCSUS, Lund University, PO Box 170, 22100 Lund, Sweden; anne.jerneck@lucsus.lu.se; Tel.: +46-(0)-222-05-12

Received: 23 December 2017; Accepted: 22 February 2018; Published: 28 February 2018

\begin{abstract}
Adaptation and mitigation are two key responses to climate change. In the global South they prompt many questions: what is the direction and degree of change needed? How can new climate change policies be aligned with existing development initiatives? How are core social relations such as gender understood and prioritized in relation to technical and other solutions? In search of synergies between adaptation, development and mitigation, this article asks a pertinent question for sub-Saharan small-scale agriculture in particular: what can adaptation and mitigation learn from development debates on social goal setting, institutional change and gender equality? From the perspective of sustainability science and feminist literature, three main findings emerge. First, as regards social goal setting, adaptation and mitigation should, like development, support the escape out of poverty, ill-health and food-insecurity. Second, as regards institutions, adaptation and mitigation should address how gender regulates access to, use of and control over resources in terms of labor, land and strategic decision-making power. Third, as regards gender equality, adaptation and mitigation should learn from how development in theory and practice has addressed gender, women, nature and the environment. At its core, the analysis contributes twelve salient themes that can significantly inform adaptation and mitigation in research, policy and practice, thus serving as inspiration for a critical debate on much needed synergetic trajectories.
\end{abstract}

Keywords: adaptation; climate change; development; environment; gender; sustainability science

\section{Introduction}

Climate change impacts are expected to become more forceful and frequent, not least in sub-Saharan Africa [1-3]. But few studies have explored how adaptation and mitigation are perceived and understood at the intersections of climate change, ill-health and poverty [4]. Even fewer studies have examined how climate change is experienced in the context of poverty and gender inequality in exposed settings in rainfed small-scale agriculture in sub-Saharan Africa, which is the dominant form of livelihood for the majority of populations there [5]. Research in sustainability science has contributed to identify aspects that are vital for understanding the conditions and scope for climate change adaptation, gender equality and poverty alleviation in this region [6-8]. As one fundamental aspect of this, the food and health imperatives imply that small-scale farmers strive to secure food while fending off multiple threats to their health [6-8]. As another vital aspect, the gender imperative refers to how gender as a profound social relation manifests itself in the regulation and use of labor, land and also marital love [9]. Here, the gender order refers to how societies shape notions of masculinity and femininity through power relations and institutional set-ups while the gender regime refers to how this translates into everyday life via particular institutions in particular settings [10]. Gender regimes thus entail institutions that determine how resources are accessed, distributed and consumed, how labor is coded, recoded and divided into both productive and reproductive tasks and how social practices and responsibilities are discursively defined and fulfilled. Taken together the three 
imperatives of food, health and gender, influence how farmers will perceive risk, prioritize tasks in everyday farming, experience and share hardship, and shape aspirations for future livelihoods [6-8]. In all, the imperatives affect farmers' adaptation and mitigation space and should be core to serious climate change responses or development initiatives [11]. The many linkages between agriculture, food and health along with gender rights issues in exposed rural areas therefore need more attention and research, especially from feminist perspectives [12]. But what else needs to be done?

Observers have argued that adaptation and mitigation, should be tackled in parallel to or in combination with development, partly due to overlaps, potential synergies [13] or the need for mainstreaming [14] but perhaps mainly because climate change is 'redefining what development policies can accomplish' [15]. It is also argued that potential synergies between adaptation, mitigation and development may instead result in trade-offs-between initiatives or interventions that would serve either adaptation, development or mitigation the best-and we therefore need a critical and varied theoretical approach to the search for triple-win strategies and the design of appropriate policies [16]. By taking such a critical stance, I will argue that development can deliver useful lessons for both adaptation and mitigation on issues of social and institutional change. Issues that we must understand theoretically before we could even think of triple-wins. For guidance, I proceed from the following question: What can adaptation and mitigation learn from development debates on social goal setting, institutional change and gender equality?

\section{Methodology}

The overall frame in this article is sustainability science. As an emerging scientific field, it seeks to capture the complexity of social and natural dimensions of sustainability [17-19] and with its ambition to deliver integrated knowledge for social change [20] it allows and encourages pluralism in theory and methods [21,22]. Inspiration for the article springs from three sources. First, sustainability science research on human-environmental conditions for food security, improved health and gender equality in sub-Saharan small-scale agriculture [6-8,11]. Second, feminist ideas in the three development debates on 'gendering development' [23], 'mainstreaming gender' [24] and 'stand-alone goals for gender equality' [25]. Third, literature on global-to local power asymmetries in the distribution, procedures and recognition of climate justice in the processes of adaptation, mitigation and development [26-28].

The article builds on three types of reviews. In the brief overview of the emerging debate on gender in the context of climate change, I do a quick quantitative meta-review (Section 2). To describe climate change impacts and responses, especially in the global South and therein sub-Saharan Africa, I do a focused review of current research in the field (Section 3). On the mature development debate, especially that on women and gender, I do a narrative review to trace main ideas, capture core concepts, identify recurring issues, locate significant controversies and harness recent insights.

As regards the specific method for identifying and defining the themes, I followed a two-way strategy. First, I started out from Nancy Fraser's trinity on global justice (recognition, redistribution, representation) [28] as a theoretical guide to locate central themes in the field of global environmental change-with a special focus on climate change adaptation in the global South. Fraser [28] suggests that we need a frame of global justice to combine the economic dimension of redistribution, with the cultural one of recognition and the political one of representation. Second, and building on my previous work on how poverty is both associated with and situated in the discourses of adaptation, development, gender and environment [17-19,22], I continued to search the scientific literature for writings on 'women in/and development', 'gender in/and development' and 'gender in/and environment'. Such purposive sampling helped in selecting central issues. At the end of this dual process, my procedure was to match the two samples, cluster them into themes and then distill the most salient of those for further discussion, thus the twelve themes in Section 4.

The text has five sections. In Section 2, I define core concepts in adaptation and explain the rationale for gender sensitive research on development and sustainability. In Section 3, I focus on global inequality along the lines of where it is located (space, time), how it can be overcome in the context 
of adaptation and development (reform, transformation) and at what scales (local, multiple). More specifically, that discussion comprises three main issues: inequality in causes, impacts and responses to climate change; variation in framings and understandings of adaptation and the associated need for social change that it triggers; and opportunities for adaptation and mitigation in small-scale agriculture in the context of multi-scalar stressors. In Section 4, I draw on the development discourse to define twelve themes of relevance for the gender dynamics of poverty and inequality in small-scale agriculture, all with implications for climate change responses. In Section 5, I conclude with insights gained for research, policy and practice.

\section{Climate Change and Gender}

IPCC defines climate change adaptation as 'adjustment in natural or human systems in response to actual or expected climate stimuli or their effects which moderates harm or exploits beneficial opportunities' [29]. As confirmed by IPCC [30] and others [31], mainstream literature often strips climate change adaptation of its human content and social context by tying it to economic tools, such as insurance policies, or technology, such as climate-proofing of infrastructure. Meanwhile, adaptation as social change or change in livelihood activities gets less attention [32]. That void, which may have dire consequences for poverty alleviation, is in focus here, especially from the position of sub-Saharan farming communities as one of the most climate change vulnerable entities on earth [3].

Adaptation and mitigation are responses to climate change with socially, spatially and temporally differentiated outcomes. Mitigation refers to the reduction of future climate change, whereas adaptation means adjusting to actual or expected climate effects. Adaptation can be incremental serving to maintain a system/process, or transformative serving to fundamentally change system attributes. Further, it can be protective in terms of taking preventive measures against negative impacts or opportunistic in terms of taking advantage of potential beneficial effects of climate change [33]. Many impoverished communities in the global South would prioritize adaptation over mitigation but interestingly, several of the most effective adaptation strategies are equally important for both mitigation and development $[34,35]$. Such synergies can be found in altered agricultural practices [36]; improved cooking-stoves consuming less fuelwood and releasing lower emissions and fewer pollutants [34,37]; and in the technology adoption of agro-forestry [38]. However, populations who are poor and also highly exposed to climatic events may be severely constrained in promoting their own adaptation and mitigation agenda [39]. To advance their cause in international climate change negotiation and policies, it is important to demonstrate that this population is large and its potential contribution to mitigation is decisive [34]. It should also be noted that despite the promises of the MDGs and SDGs and despite fairly high economic growth rates in several sub-Saharan countries, every other person out of the nearly 800 million people in the world who suffer from extreme poverty lives in the region $[40,41]$. If poverty thus remains a persisting social problem then climate change responses must at least avoid cementing or reinforcing existing inequalities any further [34].

\section{Why Gender?}

Knowledge on how and to what extent climate change interacts with social and spatial inequality is seriously underrepresented in both policy and research [42-44]. Yet, it is likely that adaptation is gendered and that it varies across scales, space and subjectivities [45]. Critical geographers argue that social relations, practices and processes must be disentangled to make research and policy sensitive to the intersecting inequalities that surface when climate change impacts and responses cut across the intersections of age, class, ethnicity, gender and space [45]. In that mission, gender sensitive approaches are essential [46]. While measuring is a good method for generating correlations and overviews for comparison, causality must be sought more deeply in the social structures and individual practices of everyday life [23] where the gender order and gender regimes are manifested.

Due to 'limited, patchy, varied and highly contextual' evidence [47], it is not widely or profoundly confirmed if/how climate change has universally differential impact on women's and men's agency 
and achievement but data are fairly consistent with the two propositions that 'climate impacts may affect men and women differently' and 'women tend to suffer more negatively in terms of their assets and well-being' [47]. According to the WHO [48] women are harder hit by droughts, floods, heavy rains, heatwaves and water scarcity—all increasingly attributed to climate change - and suffer higher risk than men in health and life expectancy. Further, women have less access to critical information on cropping patterns and weather alerts [48]. As documented by several studies such vulnerabilities are not intrinsic to women as women but rooted in gendered divisions of land, labor, decision making power and other resources [49]. Due to the likely 'uneven impacts of climate change on women' [50] we need critical feminist studies that describe and explain such gender asymmetries [49] while keeping in mind that women obviously do not belong to a homogenous entity [51,52].

To what extent do policy and research respond to this? As regards policy and practice, documented adaptation initiatives have increased significantly since 2006 albeit from a low level, mainly in Africa, especially Kenya and most often in semi-arid agriculture [53]. In my bibliometric analysis drawing on Web of Science for searching abstracts, keywords and titles for the terms 'climate change' AND 'adaptation' AND 'gender' in research published 1 January 2000-23 December 2017, there were 337 social science articles containing the three concepts. Few of these (only teen) were published before 2009. After that the debate took off and the number of articles-and the citations they receive-increased rapidly, only to plateau in 2014. In a similar search replacing 'gender' with 'women' I found 275 articles. Out of those there is an overlap of 162 containing both 'gender' and 'women'. Adding the remaining 113 to the 337 we get 450 articles mentioning either 'gender' or 'women'. In comparison and based on the same approach, there were 12,966 social science articles on 'climate change' AND 'adaptation' published 1 January 2000-23 December 2017. Notably, my Web of Science search is only a rough indication that gender is under-represented in climate change debates and does not exclude the existence of other gender research of relevance for climate change responses.

The bad news is that published gender research on climate change may have peaked or at least plateaued but the good news is that it is plausible that it will grow with the agenda on women-environment dynamics that is gaining strength in the climate change debate [54]. Other relevant and valuable studies will be those on ethics and power [19], impacts and responses [49] and distribution and environmental justice [22]. In line with this, the IPCC 'Special Report on 1.5 Degrees' $(2018,2019)$ explicitly addresses the issue of reducing inequality (including gender inequality) in the context of climate change (www.ipcc.ch). To sum up here, there are strong reasons to encourage gender informed research on climate change responses. And since poverty and inequality are central to the debate on benefit and burdens there are strong reasons to also learn from development.

\section{Climate Change and Inequality}

Adaptation is widely recognized as one of two main response options to reduce the risks from climate change. It involves major well-known strategies such as agricultural outreach, coastal management, disaster risk management, resource management, spatial and urban planning and public health [55] (p. 268). It refers to the ability of individuals, societies and systems to cope with multi-scalar processes [56] and to evaluate information on present and future climate change in relation to planned policies, practices and infrastructure [55] (p. 268). It must be informed not only by insights on bio-physical, geo-morphological and hydrological conditions but also by those on socio-technological conditions and relations. And it needs to reduce exposure and vulnerability while also increasing capacity to resist or recover from the potential adverse impacts of climate extremes and events [57].

There is a risk of reaching limits to adaptation especially in places that are most exposed to climate change impacts such as sub-Saharan agriculture where development or transformation, rather than merely adjustment, should be a main purpose of adaptation [30]. Here the question will arise of who gets to decide the direction, depth and distributional outcome of social change. And who gets to define and grasp potential opportunities when climate change responses are embedded in, mediated by and 'underpinned by diverse values' varying across contexts and cultures $[58,59]$ ? 


\subsection{Where Are the Inequalities: In Space and Time?}

In contrast to other environmental debates, the climate change debate has been less focused on the local and on communities and less focused on agency, identity and gender [60]. But with strong and growing evidence that frequent droughts, intense heat waves and serious flooding will be socially and spatially differentiated $[3,61]$ the global effort to mitigate must be combined with practical local policies that address variations in capacities, real experiences and potential initiatives. Importantly, complexity grows drastically when the focus is shifted from the global to the local where climate change impacts encounter major social forces ranging from commodification and marketization to regulation, technological shifts and large-scale interventions in the environment [62].

There are also temporal inequalities. In sub-Saharan Africa, where climate change already affects natural resources and rural livelihoods due to recurring floods and droughts $[3,44]$ access to multi-scalar and systematic knowledge on climate change adaptation and mitigation may help farmers to adapt their livelihoods in the short run while also informing policy on human security and wellbeing. But when short term measures such as asserting well-known strategies or introducing new specific practices, block or postpone necessary long-term change this may result in mal-adaptation rather than adaptation [63] (p. 741). Ill-advised efforts to protect 'human security' and improve 'wellbeing' may end up masking not only existing inequality [64] but also other precarious conditions that amplify the need to adapt [65].

The increasing number of studies on climate change responses is still disproportionate to the importance of the issue. Despite substantial investments in research, practical progress is slow, partly due to how adaptation is framed and understood [53]. But also, because adaptation and mitigation, like development, are inseparable from the socio-ecological context and need to be studied there. In doing so, observers must know that responses will be highly influenced by historical conditions and properties emerging in the cause of action [66]. Universal recipes are thus not necessarily productive in addressing climate change and donors must 'refuse to know exactly what should be done or how' [67]. Instead, climate change adaptation and mitigation in a specific setting can be prepared through concrete 'ground work actions' comprising public awareness raising and the use of appropriate institutional guidelines [53]. All of this can also be aligned with appropriate development initiatives.

\subsection{How Much Social Change Is Needed: Reform or Transformation?}

Adaptation is closely associated with climate change vulnerability and how we speak of their entwinement will affect how we act [68]. IPCC sees climate impacts as a main source of vulnerability and calls for adaptation as adjustment; others locate risks not only in nature but also in society itself as a source of vulnerability and thus call for adaptation as development or reform to reduce vulnerability within prevailing systems; but little research explores the underlying social drivers of vulnerability or the need to understand and implement climate change responses as transformative climate action $[69,70]$ or as profound political-economic transformation [68].

In the global South, ideological and theoretical assumptions about development may influence interpretations of adaptation and vulnerability [67]. This prompts the question of whether responses should entail adjustments to current activities or imply fundamental change that needs to be negotiated [57] (p. 3). Using climate change responses to reconstitute conventional growth driven development is not necessarily acceptable, efficient, or fair, particularly not from a post-development perspective focusing on the tension between climate change drivers in the global North and aspirations for social change in the global South [67]. And as mentioned above, economic growth may not work for large populations that are poor in sub-Saharan Africa [40,41]. Instead, responses should go beyond conventional development and thus seek to implement the many unfulfilled promises to reduce inequality and poverty while enhancing sustainability [17]. 


\subsection{What about Scales: Community Based or Multi-Scalar Adaptation in Small-Scale Farming?}

Despite increasing concentration in global food supply chains, it is widely documented that smallholder farms are essential for providing food and nutrients in low-income and middle-income countries where they contribute decisively to the agricultural economy [71,72]. It is estimated that out of 570 million smallholder farms worldwide, some 470 million are found in sub-Saharan Africa and Asia [73] where they provide over 70 per cent of food calories for people [74]. Although the typical farm size is under two hectares of land and although all such smallholder farms in total account for only roughly twelve per cent of all agricultural land on earth [73] they have high local significance [71]. And in their struggle to make ends meet they grapple with challenges such as shrinking land size [75] and increasing impacts from climate change and climate variability.

Storms, floods, droughts and other climate events already cause problems in climate dependent livelihoods in livestock-rearing and small-scale farming. In the decades to come, climate change will worsen the situation, especially in southern Africa where projections consistently predict decreasing rainfall, intensified droughts and increasing climate variability $[3,61,76,77]$. Agriculture, biodiversity, ecosystems, water resources and human health will be adversely affected [3] when seasonal shifts, climate events and changing weather patterns become increasingly unpredictable and more intense [57]. However, since it is hard to decide what is and what is not attributable to climate change in a certain area [78] it must be understood in relation to land use change and the multiple stressors of everyday farming including food insecurity and ill-health in the context of gender issues and persistent poverty $[18,79]$.

Development practitioners and climate change observers oftentimes propose community-based actions and responses on the premise that communities do have the necessary expertise and networks to initiate appropriate activities to avoid further loss or speed up recovery [56] (p. 2). But a disproportionate focus and pressure on the local at the expense of the national or global scale can be problematic [80] and so can community-based approaches to climate change focusing on only one single challenge (climate change) rather than on interconnected aspects of vulnerability [56] (pp. 3-6). Further, the assumption that the 'community' is uniform or inclusive may underestimate inequality and diverging interests within it. Nonetheless, there are valuable lessons to be learned from successful initiatives on community-based adaptation [81].

In the global South where most people who are poor live in rural areas and depend on agriculture for their livelihoods $[5,82]$ climate change will affect the availability, distribution and quality of agricultural land. Such impact may in turn reinforce social differentiation [3]. In rural areas those who have limited access and rights to resources, while being responsible for food production, will be the most vulnerable to impacts of climate change and climate variability [83]. Gender informed data indicate that climate change will have disproportionate effects on small-scale farmers, many of whom are women in sub-Saharan agriculture depending for their living on degrading physical resources-land, water, forest products—and who are already under pressure from the multiple stressors of poverty, ill-health and food insecurity $[3,39,43]$. This is also confirmed in our research on the food, health and gender imperatives in sustainability science [11].

To sum up this section, many processes determine how climate change impacts are (and will be) experienced and acted upon by authorities, communities and individuals and also how responses will be initiated, managed and governed. In areas where people who are poor depend on agriculture for their living the key to poverty alleviation is to have access to income-generating resources, whereas the key to adaptation and mitigation is the ability to respond in mind and deed to changing (climatic) conditions [82]. Farmers who depend on a degrading natural environment will have to adapt and adjust agricultural practices to recurring droughts, flood and other calamities [3]. But adaptation and poverty alleviation are embedded in social relations and decision-making power [84] and the ability to adapt in terms of avoiding, controlling, or coping with climate change impacts on resources is deeply differentiated, especially where infrastructure is deficient [85]. Governments, local authorities and other relevant agencies must therefore enable transitions to much more sustainable livelihood 
activities, practices and strategies [86] including those of agroecology [87]. Below, I will go to the core of the argument and show what lessons we can learn from development, especially on gender, as a major social process closely associated with climate change responses. To conclude the discussion so far, it should be obvious by now, that 'new' sustainability challenges, such as climate change and land-use change, are emerging in the context of 'old' and persistent social problems such as poverty, inequality, ill-health and food-insecurity $[22,88]$. It is crucial to bear that dynamic in mind when we examine and evaluate conditions for social change.

\section{Development Dynamics: Women or Gender, Nature or Environment}

Gender shapes social relations and situations in profound ways. Through the institutions of norms, rules and values gender becomes an underlying structure 'embedded in everyday interaction' and expressed in 'perceptual, interactional and micro-political activities' [89] (pp. 125-126).

Inspired by development debates and discourses that see gender, inequality and poverty as empirically and theoretically entwined and given their relevance for climate justice, I introduce below a set of twelve salient themes as an analogy for how to think about gender and sustainability in the climate change responses of adaptation and mitigation. The intention is by no means to cover all aspects or authors in these rich debates but to describe main ideas and core concepts and to generate useful insights. In all, the themes comprise three dimensions [28]: how women (or gender) are socially defined and (politically) represented; to what extent gendered rights are recognized; and whether social and natural resources can be fairly redistributed or at least, to some extent, negotiated.

As a general rule, there are four approaches that are typical for how to address gender, each of which has its own specific foci, issues and methods: counting women and men; analyzing gender as social relations; explaining identity and diversity beyond gender, i.e., intersectionality; and reflexive questioning of knowledge production [90]. I will go beyond counting and into representation and social relations, which in turn will have implications for how we produce knowledge in the context of climate change impacts and responses. To make the discussion relevant for sub-Saharan adaptation and mitigation, which is a stated aim of the article, I start by defining vulnerability and small-scale farming because any serious climate change response must consider such conditions in that setting. These two themes are then followed by ten related themes.

\subsection{Vulnerability: Intrinsic or Socially Contingent?}

There is no single best definition of vulnerability [55]. It is often seen as intertwined with poverty but it plays out differently depending on the context. Gender scholars have argued that vulnerability is neither an intrinsic characteristic of a certain community or person [91] nor derived from a single social dimension like being poor, rural, or female [92]. Rather, it is rooted in 'patterns of practices, processes and power relations that render some groups or persons more disadvantaged than others' [91] and thus more vulnerable to risk and disaster than others [93]. Adaptive capacity is a means to reduce vulnerability. It is defined as the general ability to anticipate, absorb, accommodate to, or recover from the effects of extreme events [94]. But how is it distributed in a population?

From a gender perspective, we could argue that ability varies with gender. Climate change impacts and responses interact in complex ways with both emerging and existing gendered capacities and vulnerabilities [95] (p. 39). Depending on how social relations shape rights and responsibilities in production, reproduction and decision-making, women and men may be affected differently [50]. If women are more vulnerable to climate change impacts they may also be disadvantaged in access to adaptation resources and adaptive capacity $[53,96]$. If vulnerability is socially determined [91] it entails not only differentiated and changing circumstances before but also during and after a disaster or hazard [92]. Thereby, it is more of a structural, relational and process-oriented condition than an individual or personal feature. 


\subsection{Defining Small-Scale Farming: Complex, Diverse and Gendered}

Small-scale farming is the dominant livelihood in sub-Saharan Africa practiced in small land-holdings by an overwhelming majority of the population (FAO 2012). There is variation across regions but women comprise at least 40 per cent and likely nearly 50 per cent of this agricultural labor force [5]. Like women in development, smallholders and family farmers have been viewed as vulnerable victims of hunger but oftentimes they are now seen as agents of change who are active in solving the food crisis [34,97]. This is partly due to the fact that smallholder livelihoods are diverse and good at producing a variety of nutrients [71]. Notably, their high diversity calls for context-specific support structures [72] especially since most mainstream agricultural intensification practices may cause agricultural diversity loss [71].

Small-scale agriculture is permeated with gendered rights, risks and responsibilities [98] caused by underlying structures of gender inequality [12] and expressed in power asymmetries in access to land, labor and leisure time [9]. If gender determines the use and control of social and environmental resources it will also influence the capacity to adapt to climate change, climate variability and other stressors [99]. Based on her extensive review of the literature on women and agricultural production in Africa, Cheryl Doss sees the African farm household as 'enormously complex'—it is 'a diversified and multifaceted economic entity' pursuing numerous varied activities; it operates according to 'competing goals and objectives' not least due to gender; and it is involved in 'elaborate networks of credit, insurance and contracts' [98] (pp. 2086-2087). But the fact that gender is a core analytical category does not prescribe a priori what should be done, says Doss [98]. Even in cases where gendered rights, roles and responsibilities are central, the actual dynamics, practices and strategies in a certain place in relation to resources are not all that well understood and interventions including technology adoption designed for women have therefore often failed [98]. Hence, the fact that agricultural livelihoods are comprehensive should not be neglected or underestimated, as also forcefully argued by Frank Ellis [100]. Moreover and given women's work and responsibilities, it is beyond doubt that gender is fundamental to agricultural productivity and food security $[12,101]$.

\subsection{Analytical Categories: Women or Gender?}

Feminists are debating how best to choose and engage with various analytical categories. In the development discourse, the notion of 'woman/women' has often been prioritized over the relational categories of women/men or femininity/masculinity. Early works in development focused on 'woman/women' mainly to increase female visibility in gendered reproduction and production and to highlight women's precarious conditions-in health status, in labor security, in social position, in workload-and, in consequence, also the need for multiple improvements in these fields. Later debates have often seen women in their capacity as capable family breadwinners, responsible care-takers and creative entrepreneurs [22]. But, when men and masculinity are constantly ignored, neglected, and/or made invisible in these debates on women and reproductive work, then relational aspects of gender disappear and understandings of culture and society ultimately become selective or even distorted. Hence, gender is the preferred category to get a fuller picture.

For analytical reasons, we thus need to scrutinize gender dynamics through lenses that allow relational aspects to surface. However, for practical reasons and in gender politics it may be necessary to design specific policies addressing women (or men) only and for a particular setting [25]. This means that gender-responsive public policy and services may thus start from an intersectional or relational perspective to eventually form an initiative or intervention that will target a particular category of women be it activists, care givers, garment workers, single mothers, smallholders, or widows, or as in the case of ActionAid, young urban women in informal settlements [102].

Rather than thinking in more diffuse or neutral gender terms, which may in fact dilute feminist ideas, some practitioners and scholars would also argue that it is more effective and forceful, to earmark limited resources directly at women or a particular group of women. Such a strategy would 
pay attention to how women act, speak and think-be it in development or in the context of climate change—-to better serve women's needs or meet their calls for action [102,103].

\subsection{Perceptions: Women as Resourceful Agents or Vulnerable Victims—or Both?}

In debates of relevance to climate change such as those on environment-development [60], migration-development [104-106] and security and peace-building [107] 'women' who are poor are often addressed as either vulnerable victims or virtuous saviors [108] and sometimes as both victims and saviors [105] (p. 6953). The problem with this portrayal is repeatedly stressed in feminist literature [108] for at least three reasons: it overlooks the relational aspect of gender (where are men? what are their tasks?); it sees vulnerability and caretaking as something intrinsic to women (a virtue); and with its focus on individuals rather than on social relations and structures it burdens women in the global South with even more tasks and responsibilities beyond their conventional ones [22]. Further, such neoliberal constructions of poor women as rational economic agents imply a certain type of political conditioning: to enjoy rights one must fulfill ascribed responsibilities $[109,110]$.

Yet, it is also observed and argued that economic activity and productive and reproductive responsibilities in the private realm, even if burdensome, may offer some degree of bargaining power for women [111] and render them opportunities to become resourceful agents of change [112]. Although causality is hard to establish between power and desired outcomes, feminist economists oftentimes see intra-household bargaining power as a discursive resource that women (can) draw on for the sake of improving the strength of their decision-making, social position and status [113].

\subsection{Labor: Coding and Recoding_Static or Dynamic?}

Much has been said about women's work in development and about the gendering of labor in times of globalization. The literature is therefore varied and wide-ranging. It comprises debates on the status of formal versus informal work, the role of men as main providers and women as care-takers, the flow of labor from agriculture to industry and services, the crowding of female labor into the export sector and male labor into construction work, minimum wages versus living wages, the global care chain, women's increasing work load and decreasing leisure time, and more to that [114].

In sub-Saharan small-scale farming, development research has observed that changes in the gendering of work tasks occur mainly when women expand their working repertoire within agriculture and food production through diversification or when men see a chance to exploit new opportunities outside agriculture; notably, men take up women's tasks (only) when these are deemed profitable $[98,115]$. But although gender norms may appear as fixed it is found that reproductive and productive work are continuously reinterpreted in theory and practice and recoded accordingly [90]. Due to such institutional instability and fluidity, norms and rules regulating work and wages are subject to ongoing socio-cultural negotiations wherein, for example, women with intra-household bargaining power, partly arising from earning an income of their own, may become resourceful agents $[113,116]$. As we have seen, women are often situated (or even caught) at the intersection between wage-work (production) and household care (reproduction). It is not clear how adaptation will affect or be affected by these conditions but it is known that existing inequalities may morph into new ones.

\subsection{Rights: Customary or Statutory—or Both?}

People are positioned differently in terms of power over resources [117] (p. 154). Studying resource access means studying power to control resources once they are accessed. While some have direct control over resources-some have to get their resources through others or through other instances. This is seen in cases where women get agricultural land through men (i.e., mainly husbands) who inherit, own and control land [9]. A critical (gender) perspective on property relations and rights to resources that will take us beyond access only and towards the ability to use and control a particular resource, such as land, would therefore offer deeper insights than conventional property theory [117]. Across time and scales, we could study how control relates to existing institutional arrangements, such 
as the existing gender regimes of labor, land, production and reproduction and how conflict will be handled when it surfaces. Existing structures of inequality may reinforce (climate change) impacts and result in differentiated outcomes; it is therefore proposed that the heuristic use of a continually changing 'web of access relations' will allow an analysis of the dynamic processes that affect access to and control over resources [117].

Gendered norms, rules and values shape women's and men's capacities, incentives and preferences for how to access, use and control resources in small-scale farming [118]. Knowledge about the environment can be gendered, as can attitudes and abilities that influence or even determine how small-scale farmers use and manage natural resources and how they approach new farming techniques and practices $[98,115]$. Rights to resources may appear as bundles of private, common or public goods [119] and may differ between customary or statutory legal institutions [120]. In settings where state-recognized property rights are lacking, gender regimes may instead govern access to, ownership of and control over resources [121]. Rights to resources can be defined as temporary if a particular gendered activity or seasonal agricultural practice is associated with a particular resource [122] or defined as permanent if women risk losing their land rights, such as in case of divorce or widowhood [9]. Gender regimes may also shape means and motives for how to tackle climate change impacts and how to prepare for adaptation and mitigation in relation to resource management. Findings from in-depth studies on the power dynamics in gender regimes for land, labor and natural resources [9] can therefore be foundational for research on climate change responses.

It is common that women in fishing and farming communities initiate, participate in and contribute to production while having less (secure) access to the natural resources of land and fishing grounds or the social resources of capital, education and information [123]. Nevertheless, women have many reproductive responsibilities and 'every dawn brings with it a long march in search of fuel, fodder and water' [124] (p. 23). For their everyday life and long-term existence, women and men thus depend differently on energy, land, water and other natural and social resources $[98,125,126]$. Hence, it is often said that women, much more than men, face 'a litany of structural, technological and cultural barriers' [127] (p. 17). To fulfil gendered productive and reproductive responsibilities women may depend on, have an interest in and also manage natural resources well, while neither having the right to own them nor being entitled to control these same resources.

Data on sub-Saharan Africa and Asia, show that women own substantially less land than men [128]. Women are disadvantaged in many land inheritance systems where legal rights in combination with gender norms hinder them from both getting and keeping land. In areas that recognize both customary and statutory law it is especially hard to secure and enforce women's land rights [118]. In case of legal pluralism both family law and land law need to be consulted and in addition, women need to not only be aware of their rights but also have the capacity to challenge social norms that limit those rights [118]. According to some observers, such limited access and such restricted rights to essential resources make women particularly exposed and vulnerable to climate change [83], especially if crop failure, fuel shortage or water scarcity will affect their capacity to discharge what is deemed to be their food provision responsibility in relation to children and other family [129].

\subsection{Social Position and Mobility: First up, then Down?}

Social and cultural norms have been contested, challenged and changed throughout history, not the least in times of social upheaval or major technological transformation such as agrarian reform or revolution, civil conflict or international war, economic boom or bust, natural disaster or, as of late, the consequences of climate change impacts and responses. The social construction of gender in production and reproduction during such times is widely discussed in the context of East- and Southeast Asian development $[130,131]$. In the region, there are well-known historical examples of how gender norms have become fluid and flexible in the course of defining moments such as critical economic or political junctures [22]. However, the many women who entered administrative or 
esteemed economic positions in wartime or joined the labor market for wage work during economic booms often remained in charge of household work, mainly because reproductive labor is utterly resistant to gender recoding [132]. Despite women's unexpected promotion and exceptional strategic achievements during such turbulent times of recoded gender relations in the public sphere, their gains in terms of improved conditions or higher positions and status appeared fragile-and gender soon reverted to 'normal' in the wake of a major event.

\subsection{Social Relations: Integration, Exploitation or Empowerment?}

As an early proponent of gender equality within modernization theory, Ester Boserup [101] argued that women must be further integrated into the economy both to reap benefits from and to contribute to the effectiveness of development. While Boserup mainly focused on technology in small-scale agriculture others have advocated integration into other domains as well. In contrast, radical feminists have argued that women were already involved in the economy and society and even exploited in both reproductive and productive work [133]. Concerns about women's low income, heavy workload and 'time poverty' have since then been mainstreamed into much development thinking [134]. But initiatives building on the idea of women's integration and involvement in the public domain often severely neglect the role of men and masculinity in the economy or private domain thus (again) ignoring that gender is relational [135] (p. 15) only to end up with rather limited insights into society and its profoundly relational structures and interactions.

As regards empowerment, Kabeer [136] sees this as a path-dependent structural process that influences the triad of ability, capacity and willingness-in a given space and time- to accept gender norms and other social constraints or to challenge and change them. She [136] (p. 499) speaks of three practices: the ability to participate on equal terms with men in shaping and reshaping society; the capacity to exercise strategic control over one's own life; and the willingness to question one's position in society. I argue that this reasoning is relevant also for climate change adaptation and vulnerability. Again, it shows that gender and changes in gender norms, involves both individual and social processes, both agency and structure.

\subsection{Nature/Environment: Belonging to Nature—or Being Susceptible to Environmental Damage and Danger?}

The women-nature debate goes back to at least the 1970s, and it then resurged in the feminist political ecology debate in the 1990s [137]. In feminist debates, there is a recurring warning that women may run the risk of carrying the burden of environmental care because they are 'closer to nature, are hardest hit by environmental degradation and have special knowledge of natural resource systems' [54] (p. 33). Feminist researchers in the development debate who are critical of this essentialist claim and reasoning — that women have strategic but vulnerable positions vis-à-vis nature—call for nuanced interpretations of gendered relations to natural resources in agriculture, forestry and water management alike [60]. Nevertheless, essentialist arguments are still gaining ground in discussions on how women-environment dynamics are influenced by global warming [54]. According to that line of reasoning, climate change and the many alterations in natural conditions that follow from it as regards impacts and responses (e.g., environmental degradation, land-use change and water scarcity) will make women even more vulnerable if they are close to and dependent on nature. Yet, recent debates and research on gender in environment and climate change offer more nuanced insights on this showing that women do not necessarily possess any essential orientation towards nature or resource conservation [138-140]. A closer study of gendered variability within and between settings may therefore help identify influential aspects and dimensions that go beyond essentialism [118].

\subsection{Social Goals: Efficiency or Equity—or Environmental Justice?}

Gender has been discussed from many development angles, especially in terms of efforts to strengthen capabilities, increase empowerment and promote equality in access to credit, socio-economic opportunities and participation in community affairs. In parallel, equity in process and outcome has 
been suggested as valuable in itself but also as a means to strengthen development effectiveness [141]. For a long time, feminist economists have argued that gender inequality leads to a waste of (women's) human capital and recently it has been reiterated that gender inequality goes against economic efficiency $[109,110]$.

Researchers who provide constructive advice on how to increase both gender equality and efficiency in agricultural intervention and extension services, as well as in climate change responses and policies, have suggested a transformative gender approach [115,123]. It will follow an 'empowerment pathway' [115] that actively involves both women and men and actively rethinks the coding of male and female working tasks $[37,115]$. The approach would not only seek to make gradual improvements to meet women's (immediate) needs but it would also engage with men more profoundly to facilitate and enable a change in the gendered coding of responsibilities as well as in long term gender relations. For that, we would have to use methods that better fit the given agricultural context, reach women and men at places and times that are convenient to their reproductive and productive responsibilities, and acknowledge gender priorities and variation in labor productivity, risk aversion strategies and time use [123].

Moreover, in times of climate change, all aspirations and promises associated with development [95] (p. 39) must now consider not only existing gender inequalities and inefficiencies but also new and emerging gendered vulnerabilities. Given the mounting calls for environmental justice and the precarious situation in small-scale farming, policymakers and researchers alike must consider, more profoundly, the gender dynamics of climate change [142] as well as other intersectional effects on equality and efficiency from climate change impacts and responses $[99,126]$.

\subsection{Norms and Power: Fixed—or Flexible and Fluid?}

By problematizing space and time, feminists have noted that everyday practices generate gendered processes that create 'separate spheres'. One common such distinction is that between the public and the private realm each characterized by certain priorities and privileges. Within the private realm gendered space is often separated further into areas of cooking, living and working operating under the rule of social norms [111]. But for long, gender scholars studying production and reproduction have also argued that for women and women's work the distinction between the private and the public cannot be taken for given [114]. Gendered norms, rules and values may be challenged in the course of social and human-environmental interaction; and while some boundaries and relations seem to be fixed others are more fluid or flexible [115].

After a climate induced extreme event, gender specific impacts may exacerbate gendered relations and responsibilities, while new obligations arise [143]. As an example, (women's) duties and workloads relating to climate change adaptation and mitigation may increase if new tasks are added on to existing ones [134]. Conversely, the distribution of specific tasks may become more equal if work associated with that task is re-coded from being feminine to becoming masculine meaning that men assume women's tasks and vice versa as happened in a severe drought in Cambodia when women and men reinterpreted, shifted and shared tasks and duties in agriculture to overcome shared burdens and difficulties [132,143]. A major crisis may reinforce gender-based disadvantages but, on the contrary, it may also, as discussed above, entail negotiations and alterations in seemingly fixed gender relations thus implying a destabilization of gender and an opening for social change.

Finally, from economic history we know that any major process of social change involves technological change [144]. Hence, as my last and highly relevant analogy for climate change adaptation and mitigation, I conclude with a theme that illustrates how technology adoption depend on social relations and institutional arrangements, such as the gender regime. The reasoning below is rooted in development while the search for solutions is inspired by sustainability science. 


\subsection{Technology Uptake: Adopt—or Not Adopt?}

Research on technology uptake in the context of rural poverty, such as agro-forestry adoption, indicates that it is a complex nonlinear process with uncertain outcomes where attitudes, knowledge and perceptions among adopters, relating to the potential benefits and challenges of the technology, are crucial [145]. Despite clear perceptions, deep knowledge of and positive attitudes towards the multiple benefits of forestry and trees, research on agro-forestry adoption indicates that reluctance to adopt may stem from the risk of investing in a technology with mainly future rather than immediate gains. In addition, adopters may be restricted by social conditions and relations, some of which go beyond technology such as the imperatives of meeting everyday food and health needs. Here research has increasingly recognized how technology adoption affects labor division and resource use within households $[7,11,12]$. New technology may not only save time or alleviate the work burden but instead impose serious time constraints owing to gendered responsibilities and the gender division of labor thereby resulting in growing work burdens-especially for women $[7,11]$. Time-saving benefits from a given technology uptake clearly depend on 'what activities will replace the hours formerly spent' [98] (p. 2088). Hence, we need to ask if the time saved is of practical value, meaning that women would use it for further household chores thus adding to their work load, or if it is of strategic value meaning that it could be used for leisure or to enhance their own interests [136]? The conditions for technology adoption may appear as local and as determined by the gender regime but if conditions are multi-scalar manifestations of higher order processes in society, such as the gender order, they will be seen as political and more general and require an understanding of more fundamental structures.

As a final note here, it is worth mentioning that repeating previously successful technology uptake may be unhelpful in light of changing conditions under climate change.

\subsection{Learning from Development}

By now, it has become obvious from the discussion, that in a given setting, women's and men's experiences of climate change and climate variability may vary due to local gender regimes and norms, as may also their perceptions of the associated risks, their priorities in how to tackle them, their perceived needs and skills in technology uptake, their rights to and decision-making power regarding environmental resources and their thoughts about adaptation and mitigation in response to climate change [34,37]. Such differences may be rooted in and driven by gendered livelihood activities and farming practices and in how women and men depend on and act differently in relation to environmental resources owing to varied productive and reproductive responsibilities $[125,126]$. But we also noticed that these conditions are malleable rather than cast in stone. Tasks may shift or be shared rather than stay strictly gender coded or divided, especially in times of major social change.

In reply to my research question, I distilled twelve gendered lessons from development to show that adaptation, as a major social process of our time, is in many instances not only similar to but should also be entwined with development and potentially also with mitigation. The twelve lessons may therefore shed gender sensitive light on the conditions for climate change responses.

\section{Conclusions}

With a focus on climate change responses, mainly adaptation but also mitigation and with the intention to learn lessons for small-scale agriculture mainly in sub-Saharan Africa, I discussed the following question: what can adaptation and mitigation learn from development debates on social goals, institutional change and gender equality?

Climate change is a transboundary process that, in response, requires multifaceted understandings as a basis for entering multi-scalar agreements, joint initiatives and potential solutions. In all, climate change drivers and impacts are inherently unequal and responses are difficult to implement due to conflicting decisions and priorities at multiple scales on everything from resource use to the degree and direction of social change-and for whom. This makes it into a power laden phenomenon influencing 
both existing and future inequalities [146]. And if we are interested in how material inequalities intersect with discursive issues we need to address not only 'who gets what' in terms of resources and services but also who 'gets to interpret' and 'who gets to represent' the needs and wants of others [147].

Development has addressed women, gender, nature and environment differently over time and in varied domains and debates [22]. From that we have learned how the power and dynamics of gender play out in the context of multiple stressors such as food insecurity, ill-health, poverty, inequality and land-use change. By viewing adaptation, development and mitigation as major related processes and with institutional change and technology uptake as part of all three, one can compare preconditions for and pathways to gender informed social change.

From a feminist sustainability science perspective on climate change adaptation and with a gender lens on the development discourse, three main findings emerge. First, the social goal of climate change responses is obviously to respond to impacts, in both a proactive and reactive way. Ideally, responses would mitigate environmental change simultaneously and synergistically with tackling food insecurity, ill-health, inequality and poverty. Second, while doing so politicians, policymakers and practitioners would have to continually take gender into consideration as a defining institution in small-scale agriculture as regards both the discursive portrayal of wo/men and the more material distribution of rights, risks and responsibilities. Third, such responses, which would take not only technological solutions but also social relations seriously, should consider structural and institutional change pertaining to norms, rules and values, as a way to alleviate the pressure from multiple stressors while also having a synergetic and transformative potential towards increased sustainability.

To conclude, gender is contingent and culturally constructed through norms, rules and values but social relations are also subject to change during major social processes such as those in focus here. In the analysis, it became clear that gender is a critical social category and also a salient feature of both development and climate change. It has many institutional and structural implications for adaptation and mitigation as well as many practical implications for environmental justice. Beyond that it also enriches the very understanding of climate change impacts and responses-and gender debates provide reasoning and tools for how policy and practice for increased development and sustainability can deal with that.

Acknowledgments: The research was funded by the Swedish Research Council Formas through the Linnaeus grants LUCID, Lund University Centre of Excellence for integration of Social and Natural Dimensions of Sustainability (259-2008-1718) and The Rush for Land in Africa (2012/7689). I am grateful to LUCID colleagues who commented on early ideas developed in this article. I would also like to thank two anonymous reviewers for constructive comments.

Conflicts of Interest: The author declares no conflict of interest.

\section{References}

1. Lobell, D.B.; Burke, M.B.; Tebaldi, C.; Mastrandrea, M.D.; Falcon, W.P.; Naylor, R.L. Prioritizing climate change adaptation needs for food security in 2030. Science 2008, 319, 607-610. [CrossRef] [PubMed]

2. Field, C.B.; Barros, V.R.; Dokken, D.J.; Mach, K.J.; Mastrandrea, M.D.; Bilir, T.E.; Chatterjee, M.; Ebi, K.L.; Estrada, Y.O.; Genova, R.C.; et al. Climate Change 2014: Impacts, Adaptation, and Vulnerability; Contribution of Working Group II to the FIFTH Assessment Report of the Intergovernmental Panel on Climate change; Cambridge University Press: Cambridge, UK; New York, NY, USA, 2014; p. 3000.

3. World Bank. Turn Down the Heat: Why a 4 Degree Warmer World Must Be Avoided; World Bank: Washington DC, USA, 2012.

4. Moser, S.C. Communicating adaptation to climate change: The art and science of public engagement when climate change comes home. Wiley Interdiscip. Rev. Clim. Chang. 2014, 5, 337-358. [CrossRef]

5. Food and Agriculture Organization (FAO). Smallholders and Family Farmers. In Sustainability Pathways; Food and Agriculture Organization: Rome, Italy, 2012; p. 4.

6. Gabrielsson, S.; Brogaard, S.; Jerneck, A. Living without buffers-Illustrating climate vulnerability in the lake victoria basin. Sustain. Sci. 2013, 8, 143-157. [CrossRef] 
7. Jerneck, A.; Olsson, L. More than trees! Understanding the agroforestry adoption gap in subsistence agriculture: Insights from narrative walks in Kenya. J. Rural Stud. 2013, 32, 114-125. [CrossRef]

8. Gabrielsson, S. Gender Matters. In Climate Change Adaptation and Development: Transforming Paradigms and Practices; Routledge: Abingdon, UK, 2014; Volume 83.

9. Steen, K. Time to Farm: A Qualitative Inquiry into the Dynamics of the Gender Regime of Land and Labour Rights in Subsistence Farming: An Example from the Chiweshe Communal Area, Zimbabwe; Lund University Centre for Sustainability Science (LUCSUS): Lund, Sweden, 2011; Volume 2.

10. Connell, R. Gender and Power: Society, the Person, and Sexual Politics; Blackwell's: Oxford, UK, 2003.

11. Jerneck, A.; Olsson, L. Food first! Theorising agroforestry adoption in smallscale agriculture: Risk evaders, opportunity seekers and the 'food imperative'. Int. J. Agric. Sustain. 2014, 32, 114-125.

12. Meinzen-Dick, R.; Quisumbing, A.R.; Behrman, J.A. A System that Delivers: Integrating Gender into Agricultural Research, Development, and Extension. In Gender in Agriculture; Springer: New York, NY, USA, 2014; pp. 373-391.

13. Mitchell, T.; Maxwell, S. Policy brief: Defining Climate Compatible Development. Available online: https:/ / cdkn. org/resource/defining-climate-compatible-development-3/?loclang=en_gb (accessed on 26 February 2018).

14. Klein, R.J.T.; Schipper, E.L.F.; Dessai, S. Integrating mitigation and adaptation into climate and development policy: Three research questions. Environ. Sci. Pol. 2005, 8, 579-588. [CrossRef]

15. Agrawal, A.; Lemos, M.C. Adaptive development. Nat. Clim. Chang. 2015, 5, 185-187. [CrossRef]

16. Ficklin, L.; Stringer, L.C.; Dougill, A.J.; Sallu, S.M. Climate compatible development reconsidered: Calling for a critical perspective. Clim. Dev. 2017, 1-4. [CrossRef]

17. Jerneck, A.; Olsson, L. Adaptation and the poor-Development, resilience, transition. Clim. Pol. 2008, 8, 170-182. [CrossRef]

18. Jerneck, A.; Olsson, L.; Ness, B.; Anderberg, S.; Baier, M.; Clark, E.; Hickler, T.; Hornborg, A.; Kronsell, A.; Lövbrand, E.; et al. Structuring sustainability science. Sustain. Sci. 2011, 6, 69-82. [CrossRef]

19. Moosa, C.S.; Tuana, N. Mapping a research agenda concerning gender and climate change: A review of the literature. Hypatia 2014, 29, 677-694. [CrossRef]

20. Shahadu, H. Towards an umbrella science of sustainability. Sustain. Sci. 2016, 11, 777-788. [CrossRef]

21. Isgren, E.; Jerneck, A.; O’Byrne, D. Pluralism in search of sustainability: Ethics, knowledge and methodology in sustainability science. Chall. Sustain. 2017, in press. [CrossRef]

22. Jerneck, A. Understanding poverty: Seeking synergies between the three discourses of development, gender, and environment. SAGE Open 2015, 5, 1-16. [CrossRef]

23. Jönsson, K.; Jerneck, A.; Arvidson, M. Politics and Development in a Globalised World; Studentlitteratur: Lund, Sweden, 2012; p. 200.

24. Parpart, J.L. Exploring the transformative potential of gender mainstreaming in international development institutions. J. Int. Dev. 2014, 26, 382-395. [CrossRef]

25. UN Women. A Transformative Stand-Alone Goal on Achieving Gender Equality, Women's Rights and Women's Empowerment: Imperatives and Key Components; UN Women: New York, NY, USA, 2013; p. 35.

26. Popke, J.; Curtis, S.; Gamble, D.W. A social justice framing of climate change discourse and policy: Adaptation, resilience and vulnerability in a Jamaican agricultural landscape. Geoforum 2016, 73, 70-80. [CrossRef]

27. Whyte, K.P. Indigenous women, climate change impacts, and collective action. Hypatia 2014, 29, 599-616. [CrossRef]

28. Fraser, N. Scales of Justice: Reimagining Political Space in a Globalizing World; Columbia University Press: New York, NY, USA, 2009; p. 215.

29. Intergovernmental Panel on Climate Change. Climate Change 2007: Impacts, Adaptation and Vulnerability; Oxford University Press: Oxford, UK, 2007.

30. Noble, I.R.; Huq, S.; Anokhin, Y.A.; Carmin, J.; Goudou, D.; Lansigan, F.P.; Osman-Elasha, B.; Villamizar, A. Adaptation Needs and Options. In Climate Change 2014: Impacts, Adaptation, and Vulnerability. Part A: Global and Sectoral Aspects; Field, C.B., Barros, V.R., Dokken, D.J., Mach, K.J., Mastrandrea, M.D., Bilir, T.E., Chatterjee, M., Ebi, K.L., Estrada, Y.O., Genova, R.C., et al., Eds.; Contribution of Working Group II to the Fifth Assessment Report of the Intergovernmental Panel of Climate Change; Cambridge University Press: Cambridge, UK; New York, NY, USA, 2014; pp. 833-868. 
31. Leighton, M.; Shen, X.; Warner, K.; Wendeler, A.; Brach, K. Climate Change and Migration: Rethinking Policies for Adaptation and Disaster Risk Reduction; United Nations University Institute for Environment and Human Security: Bonn, Germany, 2011.

32. Khan, M.R.; Roberts, J.T. Adaptation and international climate policy. Wiley Interdiscip. Rev. Clim. Chang. 2013, 4, 171-189. [CrossRef]

33. Intergovernmental Panel on Climate Change. Glossary. In Climate Change 2014; Field, C.B., Barros, V., Dokken, D., Mach, K.J., Mastrandrea, M.D., Bilir, T.E., Chatterjee, M., Ebi, K.L., Estrada, Y.O., Genova, R.C., et al., Eds.; Cambridge University Press: Cambridge, UK; New York, NY, USA, 2014.

34. Olsson, L.; Jerneck, A. Farmers fighting climate change - from victims to agents in subsistence livelihods. Wiley Interdiscip. Rev. Clim. Chang. 2010, 1, 363-373. [CrossRef]

35. Tschakert, P.; Olsson, L. Post-2012 climate action in the broad framework of sustainable development policies: The role of the EU. Clim. Pol. 2005, 5, 329-348. [CrossRef]

36. Farage, P.; Ardö, J.; Olsson, L.; Rienzi, E.; Ball, A.; Pretty, J. The potential for soil carbon sequestration in three tropical dryland farming systems of Africa and Latin America: A modelling approach. Soil Tillage Res. 2007, 94, 457-472. [CrossRef]

37. Jerneck, A.; Olsson, L. A smoke-free kitchen: Initiating community based co-production for cleaner cooking and cuts in carbon emissions. J. Clean. Prod. 2012, 60, 208-215. [CrossRef]

38. Sanchez, P.A. Linking climate change research with food security and poverty reduction in the tropics. Agric. Ecosyst. Environ. 2000, 82, 371-383. [CrossRef]

39. United Nations Development Programme (UNDP). Resource Guide on Gender and Climate Change Geneva; United Nations Development Programme: New York, NY, USA, 2009; p. 151.

40. Chandy, L. Why Is the Number of Poor People in Africa Increasing When Africa's Economies Are Growing?; Brookings Institute: Washington DC, USA, 2015.

41. Dang, H.-A.; Dabalen, A. Is Poverty in Africa Mostly Chronic or Transient? Evidence from Synthetic Panel Data. Available online: https:/ / editorialexpress.com/cgi-bin/conference/download.cgi?db_name= CSAE2017\&paper_id=1087 (accessed on 27 February 2018).

42. Dankelman, I. Gender and Climate Change: An Introduction; Routledge: Abingdon, UK, 2010.

43. Hammond, V. Gender, Climate Change and the United Nations: A Gender Analysis of Climate Change and Recent United Nations Framework Convention on Climate Change Agreements, with Particular Reference to Their Implications in Sub-Saharan Africa, 2012. Available online: https:/ / www.gender.net/fileadm/ inhalte/literaturdateien (accessed on 12 March 2015).

44. Olsson, L.; Opondo, M.; Tschakert, P.; Agrawal, A.; Eriksen, S.H.; Ma, S.; Perch, L.N.; Zakieldeen, S.A. Livelihoods and poverty. In Climate Change 2014: Impacts, Adaptation, and Vulnerability. Part A: Global and Sectoral Aspects; Field, C.B., Barros, V.R., Dokken, D.J., Mach, K.J., Mastrandrea, M.D., Bilir, T.E., Chatterjee, M., Ebi, K.L., Estrada, Y.O., Genova, R.C., et al., Eds.; Contribution of Working Group II to the Fifth Assessment Report of the IPCC; Cambridge University Press: Cambridge, UK; New York, NY, USA, 2014; pp. 793-832.

45. Sultana, F. Gendering climate change: Geographical insights. Prof. Geogr. 2014, 66, 372-381. [CrossRef]

46. Alston, M. Gender Mainstreaming and Climate Change. Women's Stud. Int. Forum 2014, 47, $287-294$. [CrossRef]

47. Goh, A.H. A Literature Review of the Gender-Differentiated Impacts of Climate Change on Women's and Men's Assets and Well-Being in Developing Countries; CAPRi Work; International Food Policy Research Institute: Washington, DC, USA, 2012.

48. World Health Organization (WHO). Gender, Climate Change and Health; 9241508183; World Health Organization: Geneva, Switzerland, 2014.

49. Pearse, R. Gender and climate change. Wiley Interdiscip. Rev. Clim. Chang. 2017, 8, e451. [CrossRef]

50. Alston, M. Women and adaptation. Wiley Interdiscip. Rev. Clim. Chang. 2013, 4, 351-358. [CrossRef]

51. Bhattarai, B.; Beilin, R.; Ford, R. Gender, agrobiodiversity, and climate change: A study of adaptation practices in the Nepal Himalayas. World Dev. 2015, 70, 122-132. [CrossRef]

52. Van Aelst, K.; Holvoet, N. Intersections of gender and marital status in accessing climate change adaptation: Evidence from rural Tanzania. World Dev. 2016, 79, 40-50. [CrossRef]

53. Ford, J.D.; Berrang-Ford, L.; Bunce, A.; McKay, C.; Irwin, M.; Pearce, T. The status of climate change adaptation in Africa and Asia. Reg. Environ. Chang. 2015, 15, 801-814. [CrossRef] 
54. Resurrección, B.P. Persistent women and environment linkages in climate change and sustainable development agendas. Women's Stud. Int. Forum 2013, 40, 33-43. [CrossRef]

55. Füssel, H.M. Adaptation planning for climate change: Concepts, assessment approaches, and key lessons. Sustain. Sci. 2007, 2, 265-275. [CrossRef]

56. Dodman, D.; Mitlin, D. Challenges for community-based adaptation: Discovering the potential for transformation. J. Int. Dev. 2013, 25, 640-659. [CrossRef]

57. Field, C.B.; Barros, V.; Stocker, T.F.; Qin, D.; Dokken, D.; Ebi, K.; Mastrandrea, M.; Mach, K.; Plattner, G.; Allen, S. Managing the Risks of Extreme Events and Disasters to Advance Climate Change Adaptation; Cambridge University Press: Cambridge, UK; New York, NY, USA, 2012.

58. Adger, W.N.; Dessai, S.; Goulden, M.; Hulme, M.; Lorenzoni, I.; Nelson, D.R.; Naess, L.O.; Wolf, J.; Wreford, A. Are there social limits to adaptation to climate change? Clim. Chang. 2009, 93, 335-354. [CrossRef]

59. Adger, N.; Barnett, J.; Dabelko, G. Climate and war: A call for more research. Nature 2013, 498, 171. [CrossRef] [PubMed]

60. Leach, M. Earth mother myths and other ecofeminist fables: How a strategic notion rose and fell. Dev. Chang. 2007, 38, 67-85. [CrossRef]

61. Intergovernmental Panel on Climate Change. Summary for Policymakers. In Climate Change 2014: Impacts, Adaptation, and Vulnerability. Part A: Global and Sectoral Aspects; Contribution of Working Group II to the Fifth Assessment Report of the Intergovernmental Panel on Climate Change; Cambridge University Press: Cambridge, UK, 2014.

62. O'Brien, K.L.; Wolf, J. A values-based approach to vulnerability and adaptation to climate change. Wiley Interdiscip. Rev. Clim. Chang. 2010, 1, 232-242. [CrossRef]

63. Brooks, N.; Grist, N.; Brown, K. Development futures in the context of climate change: Challenging the present and learning from the past. Dev. Policy Rev. 2009, 27, 741-765. [CrossRef]

64. Hudson, H. 'Doing'security as though humans matter: A feminist perspective on gender and the politics of human security. Secur. Dialogue 2005, 36, 155-174. [CrossRef]

65. Inderberg, T.H.; Eriksen, S.; O’Brien, K.; Sygna, L. Climate Change Adaptation and Development: Transforming Paradigms and Practices; Routledge: Abingdon, UK, 2014.

66. Wise, R.; Fazey, I.; Smith, M.S.; Park, S.; Eakin, H.; Van Garderen, E.A.; Campbell, B. Reconceptualising adaptation to climate change as part of pathways of change and response. Glob. Environ. Chang. 2014, 28, 325-336. [CrossRef]

67. Ireland, P.; McKinnon, K. Strategic localism for an uncertain world: A postdevelopment approach to climate change adaptation. Geoforum 2013, 47, 158-166. [CrossRef]

68. Bassett, T.J.; Fogelman, C. Déjà vu or something new? The adaptation concept in the climate change literature. Geoforum 2013, 48, 42-53. [CrossRef]

69. Pelling, M.; Manuel-Navarrete, D. From resilience to transformation: The adaptive cycle in two mexican urban centers. Ecol. Soc. 2011, 16, 11. [CrossRef]

70. Ribot, J. Vulnerability before adaptation: Toward transformative climate action. Glob. Environ. Chang. 2011, 21, 1160-1162. [CrossRef]

71. Herrero, M.; Thornton, P.K.; Power, B.; Bogard, J.R.; Remans, R.; Fritz, S.; Gerber, J.S.; Nelson, G.; See, L.; Waha, K. Farming and the geography of nutrient production for human use: A transdisciplinary analysis. Lancet Planet. Health 2017, 1, e33-e42. [CrossRef]

72. Graeub, B.E.; Chappell, M.J.; Wittman, H.; Ledermann, S.; Kerr, R.B.; Gemmill-Herren, B. The state of family farms in the world. World Dev. 2016, 87, 1-15. [CrossRef]

73. Lowder, S.K.; Skoet, J.; Raney, T. The number, size, and distribution of farms, smallholder farms, and family farms worldwide. World Dev. 2016, 87, 16-29. [CrossRef]

74. Samberg, L.H.; Gerber, J.S.; Ramankutty, N.; Herrero, M.; West, P.C. Subnational distribution of average farm size and smallholder contributions to global food production. Environ. Res. Lett. 2016, 11, 124010. [CrossRef]

75. Masters, W.A.; Djurfeldt, A.A.; De Haan, C.; Hazell, P.; Jayne, T.; Jirström, M.; Reardon, T. Urbanization and farm size in Asia and Africa: Implications for food security and agricultural research. Glob. Food Secur. 2013, 2, 156-165. [CrossRef]

76. Solomon, S.; Plattner, G.-K.; Knutti, R.; Friedlingstein, P. Irreversible climate change due to carbon dioxide emissions. Proc. Natl. Acad. Sci. USA 2009, 106, 1704-1709. [CrossRef] [PubMed] 
77. Intergovernmental Panel on Climate Change. Summary for Policymakers; Working Group I Contribution to the IPCC Fifth Assessment Report Climate Change 2013: The Physical Science Basis; IPCC: Geneva, Switzerland, 2013.

78. Cramer, W.; Yohe, G.W.; Auffhammer, M.; Huggel, C.; Molau, U.; Dias, M.A.F.S.; Solow, A.; Stone, D.A.; Tibig, L. Detection and attribution of observed impacts. In Climate Change 2014: Impacts, Adaptation, and Vulnerability. Part A: Global and Sectoral Aspects; Field, C.B., Barros, V.R., Dokken, D.J., Mach, K.J., Mastrandrea, M.D., Bilir, T.E., Chatterjee, M., Ebi, K.L., Estrada, Y.O., Genova, R.C., et al., Eds.; Contribution of Working Group II to the Fifth Assessment Report of the Intergovernmental Panel of Climate Change; Cambridge University Press: Cambridge, UK; New York, NY, USA, 2014; pp. 979-1037.

79. Jerneck, A.; Olsson, L. Poverty. In Edward Elgar Encyclopedia of Global Environmental Politics and Governance; Zelli, F., Pattberg, P., Eds.; Edward Elgar Publishing: Cheltenham, UK, 2015.

80. Adger, W.N.; Arnell, N.W.; Tompkins, E.L. Successful adaptation to climate change across scales. Glob. Environ. Chang. 2005, 15, 77-86. [CrossRef]

81. Reid, H.; Schipper, E.L.F. 1 Upscaling Community-Based Adaptation. In Community-Based Adaptation to Climate Change: Scaling It Up; Routledge: Abingdon, UK, 2014.

82. Dercon, S. Rural poverty: Old challenges in new contexts. World Bank Res. Obs. 2009. [CrossRef]

83. United Nations Development Programme (UNDP). Human Development Report 2007/2008: Fighting Climate Change, Human Solidarity in a Divided World; United Nations Development Programme: New York, NY, USA, 2007.

84. De Haan, L.; Zoomers, A. Exploring the frontier of livelihoods research. Dev. Chang. 2005, 36, $27-47$. [CrossRef]

85. Klein, R.J.T.; Midgley, G.F.; Preston, B.L.; Alam, M.; Berkhout, F.G.H.; Dow, K.; Shaw, M.R. Adaptation opportunities, constraints, and limits. In Climate Change 2014: Impacts, Adaptation, and Vulnerability. Part A: Global and Sectoral Aspects; Field, C.B., Barros, V.R., Dokken, D.J., Mach, K.J., Mastrandrea, M.D., Bilir, T.E., Chatterjee, M., Ebi, K.L., Estrada, Y.O., Genova, R.C., et al., Eds.; Contribution of Working Group II to the Fifth Assessment Report of the Intergovernmental Panel of Climate Change; Cambridge University Press: Cambridge, UK; New York, NY, USA, 2014; pp. 899-943.

86. Adhikari, B. Poverty reduction through promoting alternative livelihoods: Implications for marginal drylands. J. Int. Dev. 2013, 25, 947-967. [CrossRef]

87. Isgren, E. Between Nature and Modernity; Lund University: Lund, Sweden, 2018.

88. Jerneck, A.; Olsson, L. Breaking out of sustainability impasses: How to apply frame analysis, reframing and transition theory to global health challenges. Environ. Innov. Soc. Transit. 2011, 1, 255-271. [CrossRef]

89. West, C.; Zimmerman, D.H. Doing gender. Gend. Soc. 1987, 1, 125-151. [CrossRef]

90. Reed, M.G.; Mitchell, B. Gendering environmental geography. Can. Geogr. Géogr. Can. 2003, 47, $318-337$. [CrossRef]

91. Enarson, E. Through women's eyes: A gendered research agenda for disaster social science. Disasters 1998, 22, 157-173. [CrossRef] [PubMed]

92. Blaikie, P.; Cannon, T.; Davis, I.; Wisner, B. At Risk II: Natural Hazards, People's Vulnerability and Disasters; Routledge: Abingdon, UK, 2014.

93. Hilhorst, D.; Bankoff, G. Introduction: Mapping vulnerability. In Mapping Vulnerability: Disasters, Development, and People; Hilhorst, D., Bankoff, G., Eds.; Earthscan: London, UK, 2004; pp. 1-9.

94. United Nations International Strategy for Disaster Reduction. Living with Risk: A Global Review of Disaster Reduction Initiatives; United Nations Publications: New York, NY, USA, 2004; Volume 1.

95. United Nations Development Programme (UNDP). Human Development Report 2010: The Real Wealth of Nations: Pathways to Human Development; United Nations Development Programme: New York, NY, USA, 2010.

96. Demetriades, J.; Esplen, E. The gender dimensions of poverty and climate change adaptation. IDS Bull. 2008, 39, 24-31. [CrossRef]

97. Silva, J.G.D. The Family Farming Revolution; Food and Ariculture Organisation: Rome, Italy, 2015.

98. Doss, C.R. Designing agricultural technology for African women farmers: Lessons from 25 years of experience. World Dev. 2001, 29, 2075-2092. [CrossRef] 
99. Vincent, K.E.; Tschakert, P.; Barnett, J.; Rivera-Ferre, M.G.; Woodward, A. Cross-chapter box on gender and climate change. In Climate Change 2014: Impacts, Adaptation, and Vulnerability. Part A: Global and Sectoral Aspects; Field, C.B., Barros, V.R., Dokken, D.J., Mach, K.J., Mastrandrea, M.D., Bilir, T.E., Chatterjee, M., Ebi, K.L., Estrada, Y.O., Genova, R.C., et al., Eds.; Contribution of Working Group II to the Fifth Assessment Report of the IPCC; Cambridge University Press: Cambridge, UK; New York, NY, USA, 2014; Volume 1, pp. 105-107.

100. Ellis, F. Rural Livelihoods and Diversity in Developing Countries; Oxford University Press: Oxford, UK, 2000.

101. Boserup, E. Woman's Role in Economic Development; Earthscan: London, UK, 1970; p. 274.

102. Chatterjee, B. Actionaid's young urban women programme in urban India: Taking an intersectional approach to decent work, unpaid care, and sexual and reproductive health and rights. Gend. Dev. 2015, 23, 127-143. [CrossRef]

103. Alston, M. Women and Climate Change in Bangladesh; Routledge: Abingdon, UK, 2015.

104. Jackson, C. Doing what comes naturally? Women and environment in development. World Dev. 1993, 21, 1947-1963. [CrossRef]

105. Chan, C. Gendered morality and development narratives: The case of female labor migration from indonesia. Sustainability 2014, 6, 6949-6972. [CrossRef]

106. Piper, N. The complex interconnections of the migration-development nexus: A social perspective. Popul. Space Place 2009, 15, 93-101. [CrossRef]

107. Cohn, C. Mainstreaming gender in UN security policy: A path to political transformation? Glob. Gov. Fem. Perspect. 2008, 185-206. [CrossRef]

108. Arora-Jonsson, S. Virtue and vulnerability: Discourses on women, gender and climate change. Glob. Environ. Chang. 2011, 21, 744-751. [CrossRef]

109. Caron, C.M.; Margolin, S.A. Rescuing girls, investing in girls: A critique of development fantasies. J. Int. Dev. 2015, 27, 881-897. [CrossRef]

110. Chant, S. Galvanizing girls for development? Critiquing the shift from 'smart' to 'smarter economics'. Prog. Dev. Stud. 2016, 16, 314-328. [CrossRef]

111. Jabeen, H. Adapting the built environment: The role of gender in shaping vulnerability and resilience to climate extremes in Dhaka. Environ. Urban. 2014, 26, 147-165. [CrossRef]

112. Gabrielsson, S.; Ramasar, V. Widows: Agents of change in a climate of water uncertainty. J. Clean. Prod. 2013, 60, 34-42. [CrossRef]

113. Doss, C. Intrahousehold bargaining and resource allocation in developing countries. World Bank Res. Obs. 2013, 28, 52-78. [CrossRef]

114. Pearson, R. Gender, Globalization and the Reproduction of Labour. In New frontiers in Feminist Political Economy; Routledge: Abingdon, UK, 2014; pp. 19-42.

115. Farnworth, C.; Colverson, K. Building a gender-transformative extension and advisory facilitation system in Africa. J. Gend. Agric. Food Secur. 2015, 1, 20-39.

116. Cruz-Torres, M.; McElwee, P. Gender and Sustainability: Lessons from Asia and Latin America; University of Arizona Press: Tucson, AZ, USA, 2012.

117. Ribot, J.C.; Peluso, N.L. A theory of access. Rural Sociol. 2003, 68, 153-181. [CrossRef]

118. Doss, C.; Meinzen-Dick, R.; Quisumbing, A.; Theis, S. Women in agriculture: Four myths. Glob. Food Secur. 2017. [CrossRef]

119. Schlager, E.; Ostrom, E. Property-rights regimes and natural resources: A conceptual analysis. Land Econ. 1992, 68, 249-262. [CrossRef]

120. Meinzen-Dick, R.; Kovarik, C.; Quisumbing, A. Gender and sustainability. Annu. Rev. Environ. Resour. 2014, 39, 29-55. [CrossRef]

121. Behrman, J.; Meinzen-Dick, R.; Quisumbing, A. The gender implications of large-scale land deals. J. Peasant Stud. 2012, 39, 49. [CrossRef]

122. Leach, M. Gender and the environment: Traps and opportunities. Dev. Pract. 1992, 2, 12-22. [CrossRef]

123. Manfre, C.; Rubin, D.; Allen, A.; Summerfield, G.; Colverson, K.; Akeredolu, M. Reducing the Gender Gap in Agricultural Extension and Advisory Services: How to Find the Best Fit for Men and Women Farmers. Available online: http:/ /www.culturalpractice.com/wp-content/uploads/2013/04/3-2012-39.pdf (accessed on 26 February 2018). 
124. Dankelman, I. Climate change: Learning from gender analysis and women's experiences of organising for sustainable development. Gend. Dev. 2002, 10, 21-29. [CrossRef]

125. Otzelberger, A. Gender-Responsive Strategies on Climate Change: Recent Progress and Ways Forward for Donors; Institute of Development Studies: Brighton, UK, 2011; pp. 1-58.

126. Terry, G. No climate justice without gender justice: An overview of the issues. Gend. Dev. 2009, 17, 5-18. [CrossRef]

127. Denton, F. Climate change vulnerability, impacts, and adaptation: Why does gender matter? Gend. Dev. 2002, 10, 10-20. [CrossRef]

128. Doss, C.; Kovarik, C.; Peterman, A.; Quisumbing, A.; Bold, M. Gender inequalities in ownership and control of land in Africa: Myth and reality. Agric. Econ. 2015, 46, 403-434. [CrossRef]

129. Kes, A.; Swaminathan, H. Gender and Time Poverty in Sub-Saharan Africa. In Gender, Time Use, and Poverty in Sub-Saharan Africa; World Bank Publications: Washington DC, USA, 2006; pp. 13-38.

130. Chow, E.N.-L. Transforming Gender and Development in East Asia; Routledge: Abingdon, UK, 2013.

131. Liu, J.; Yamashita, J. Routledge Handbook of Gender in East Asia; Routledge: Abingdon, UK, 2017.

132. Resurreccion, B.P. The Gender and Climate Debate: More of the Same or New Pathways of Thinking and Doing. Available online: https:/ / www.rsis.edu.sg/wp-content/uploads/rsis-pubs/NTS/resources / research_papers/MacArthur\%20Working\%20Paper_Bernadette.pdf (accessed on 27 February 2018).

133. Beneria, L.; Sen, G. Accumulation, reproduction, and 'women's role in economic development': Boserup revisited. Signs J. Women Cult. Soc. 1981, 7, 279-298. [CrossRef]

134. Blackden, C.M.; Wodon, Q. Gender, Time Use, and Poverty in Sub-Saharan Africa; World Bank Publications: Washington DC, USA, 2006.

135. Krishna, S. Redefining Sustainable Livelihoods. In Women Reclaiming Livelihoods: Spaces Lost, Spaces Gained; Palgrave Macmillan: London, UK, 2012; pp. 12-20.

136. Kabeer, N. Between affiliation and autonomy: Navigating pathways of women's empowerment and gender justice in rural Bangladesh. Dev. Chang. 2011, 42, 499-528. [CrossRef]

137. Rocheleau, D.; Thomas-Slayter, B.; Wangari, E. Gender and Environment: A Feminist Political Ecology Perspective. In Feminist Political Ecology: Global Issues and Local Experiences; Routledge: Abingdon, UK, 1996; pp. 3-26.

138. Elmhirst, R. Introducing new feminist political ecologies. Geoforum 2011, 42, 129-132. [CrossRef]

139. Leach, M. Gender Equality and Sustainable Development; Routledge: Abingdon, UK, 2015.

140. Nightingale, A.J. Environment and gender. In The International Encyclopedia of Geography; Wiley: New York, NY, USA, 2017.

141. Tinker, I. Persistent Inequalities: Women and World Development; Oxford University Press: Oxford, UK, 1990.

142. O'Neill, S.J.; Hulme, M.; Turnpenny, J.; Screen, J.A. Disciplines, geography, and gender in the framing of climate change. Bull. Am. Meteorol. Soc. 2010, 91, 997-1002. [CrossRef]

143. OXFAM. Responding to Climate Change in Vietnam: Opportunities for Improving Gender Equality; OXFAM: Hanoi, Vietnam, 2009; p. 63.

144. Cameron, R.E. A Concise Economic History of the World: From Paleolithic Times to the Present; Oxford University Press USA: New York, NY, USA, 1993; p. 435.

145. Meijer, S.S.; Catacutan, D.; Ajayi, O.C.; Sileshi, G.W.; Nieuwenhuis, M. The role of knowledge, attitudes and perceptions in the uptake of agricultural and agroforestry innovations among smallholder farmers in sub-Saharan Africa. Int. J. Agric. Sustain. 2015, 13, 40-54. [CrossRef]

146. Nightingale, A. Warming up the climate change debate: A challenge to policy based on adaptation. J. For. Livelihood 2009, 8, 84-89. [CrossRef]

147. Dahl, H.M.; Stoltz, P.; Willig, R. Recognition, redistribution and representation in capitalist global society: An interview with nancy fraser. Acta Sociol. 2004, 47, 374-382. [CrossRef]

(C) 2018 by the author. Licensee MDPI, Basel, Switzerland. This article is an open access article distributed under the terms and conditions of the Creative Commons Attribution (CC BY) license (http:// creativecommons.org/licenses/by/4.0/). 